\title{
CHARACTERIZATION AND EVALUATION OF VARIOUS MATERIALS FOR AUTOMOBILE COMPONENTS
}

\section{SHUBHAM SINGH SACHAN \& RAMNEEK SHARMA}

Department of Automobile Engineering, Chandigarh University, Gharuan, Mohali, India

\section{ABSTRACT}

This paper describes about various material (En19, En24, SAE8620 and AL6061 T6) can be used for manufacturing of automobile components in place of currently used components. Experimental studies were conducted to study their characteristics and analyse the mechanical properties. This can be done by performing hardness, impact, tensile, torsion, fatigue and double shear tests for finding of mechanical properties, and for the studies of composition, EDX analysis is performed.

KEYWORDS: Materials, Automobile, Mechanical Properties, Specimens \& Testing

Received: Jun 25, 2017; Accepted: Jul 13, 2017; Published: Jul 18, 2017; Paper Id.: IJMPERDAUG201717

\section{INTRODUCTION}

The Indian auto components industry has experienced $7 \%$ of Gross Domestic Product (GDP) over the last few years, because of a stable government framework. With increased purchasing power, large domestic market, and constantly developing infrastructure that made India a better place for investment [1]. For the production of automobile components, it required a very wide variety of raw materials including Iron $(\mathrm{Fe})$ into steel; aluminium; glass; plastics; rubber and special fibers [2]. Firstly, raw materials are mined from the earth, after that it is processed into materials. So that, auto manufacturers can use in the production of automobiles.

Currently, automotive industry is doing research and experiments into reduce the overall weight of the car, improve its safety and crash worthiness while cost is less. Steel is the best choice material from the beginning of automobile manufacturing. But now days use of aluminium is increased instead of steel, especially in body parts and bumpers of vehicles, because of its malleability, light weight nature and good shock absorbing property [3]. Many researchers concluded that new composite materials have better properties and suitable in performance. But their casting, machining, fabrication and heat treatment process may alter the properties. A vehicle is assembly of many components like transmission, axle beams, steering knuckle, chassis, leaf spring, body parts and engine components. The details about which components is made of which materials, its methods and grade are shown in Table 1.

The main aim of this research is to find the alternative grade of materials, which are not used in the casting of particular components. This can be done by studying existing materials' chemical composition, their physical properties, micro-hardness and microstructure. 
Table 1: Detailed about Material used in Automobile Components [4]

\begin{tabular}{|c|c|c|c|c|}
\hline \multicolumn{2}{|c|}{ Name of the Part } & Material Used & Method of & Material Grade \\
\hline \multirow{10}{*}{$\begin{array}{l}\text { Engine } \\
\text { Components }\end{array}$} & Cylinder & Cast iron, alloy steel & Casting & \multirow{10}{*}{$\begin{array}{l}\text { En18, En19, } \\
\text { SAE4140, 42CrMo4, SCM440, } \\
\text { En198, } \\
\text { 39Cr5, SAE1541, } \\
\text { SAE1548, 40CrMo4H, 2CrMo, } \\
\text { C38+N2, 38MnSiVS5, 38MnS6, } \\
\text { 46Mn5, CMA-1, 38MnSiVS5, C70S6 } \\
\text { S48C, S48CS1, } \\
\text { AW6060, AW6082, } \\
\text { A356 }\end{array}$} \\
\hline & $\begin{array}{l}\text { Cylinder } \\
\text { head }\end{array}$ & $\begin{array}{l}\text { Cast iron, aluminium } \\
\text { alloy }\end{array}$ & $\begin{array}{l}\text { Casting, } \\
\text { forming }\end{array}$ & \\
\hline & Piston & $\begin{array}{l}\text { Cast iron, aluminium } \\
\text { alloy }\end{array}$ & $\begin{array}{l}\text { Casting, } \\
\text { forging }\end{array}$ & \\
\hline & Piston ring & $\begin{array}{l}\text { Silicon cast iron, } \\
\text { chrome steel }\end{array}$ & Casting & \\
\hline & Piston pins & Steel & Forging & \\
\hline & Valves & Special alloy steels & Forging & \\
\hline & $\begin{array}{l}\text { Connecting } \\
\text { rod }\end{array}$ & $\begin{array}{l}\text { Nickel alloy steel, } \\
\text { aluminium, titanium, } \\
\text { iron }\end{array}$ & Forging & \\
\hline & Crankshaft & Alloy steel, SG iron & Forging & \\
\hline & Crankcase & $\begin{array}{l}\text { Aluminium alloy, } \\
\text { steel, cast iron }\end{array}$ & Casting & \\
\hline & $\begin{array}{l}\text { Cylinder } \\
\text { liner }\end{array}$ & $\begin{array}{l}\text { Cast iron, nickel alloy } \\
\text { steel }\end{array}$ & Casting & \\
\hline \multirow[b]{2}{*}{ Transmission } & Gear box & \multirow[b]{2}{*}{ Steel, Aluminium } & \multirow[b]{2}{*}{$\begin{array}{l}\text { Casting, } \\
\text { Forging }\end{array}$} & $\begin{array}{l}\text { SAE8620, SAE8625, SAE8627, } \\
\text { ETN22, ETN25, ETN27, 16MnCr5, }\end{array}$ \\
\hline & $\begin{array}{l}\text { Propeller } \\
\text { shaft }\end{array}$ & & & $\begin{array}{l}\text { 20MnCr5, SCM420, SAE4120, } \\
\text { En353, En354, SAE8822H, 815M17 }\end{array}$ \\
\hline \multicolumn{2}{|l|}{ Axle Beams } & $\begin{array}{l}\text { Cast iron, Cast } \\
\text { Aluminium, Forged } \\
\text { steel }\end{array}$ & Forging & $\begin{array}{l}\text { SAE1045M, 709M40, SAES322, } \\
\text { 40Cr4C, 41CRS4, S58C, } \\
\text { SS4510/HMnTi, 30MnVS6+Ti, } \\
\text { En15A, SAE1041, SAE1541 }\end{array}$ \\
\hline \multicolumn{2}{|c|}{ Steering Knuckle } & $\begin{array}{l}\text { Aluminium alloy, } \\
\text { Steel, Iron }\end{array}$ & Forging & $\begin{array}{l}\text { SAE4135, SCR440, SAE5137H, } \\
\text { SAE11v37,ASTM A356-T6, } \\
\text { A536,En47 }\end{array}$ \\
\hline \multicolumn{2}{|l|}{ Chassis } & Spring Steel & & SS316,AA5049, AA5454 \\
\hline \multicolumn{2}{|c|}{ Doors, closures, outer panels } & Steel, Aluminium & $\begin{array}{l}\text { Forming, } \\
\text { Forging }\end{array}$ & AA5182 \\
\hline
\end{tabular}

\section{EXPERIMENTAL DETAILS}

\section{Materials Used}

The auto-components are made by different type of materials, such as steel and aluminium. The material which is selected for the testing is SAE8620, En19, En24 and Al6061 T6.

In this paper, SAE8620 is used because of its capability of wearing resistance and toughness. En19 is used because of its ductility, shock resistance and resistance in very high loading. En24 is used because of its strength, ductility, and wear resistance. AL6061 T6 is used because of its strength, toughness, non-corrosive and applications where, heat transfer is required. T6 (temper 6) means a solution, heat treated and artificially aged.

Table 2: Physical Properties of Specimen Materials [5]

\begin{tabular}{|l|c|c|c|c|}
\hline \multicolumn{1}{|c|}{ Properties } & En19 & SAE8620 & En24 & AL6061 T6 \\
\hline Density $\left(\mathrm{g} / \mathrm{cm}^{3}\right)$ & 7.8 & 8.08 & 7.85 & 2.7 \\
\hline Melting Point $\left({ }^{\circ} \mathrm{C}\right)$ & 1540 & 1425 & 1427 & 588 \\
\hline Tensile Strength $(\mathrm{MPa})$ & 850 & 820 & 745 & 310 \\
\hline Yield Strength $(\mathrm{MPa})$ & 680 & 590 & 470 & 275 \\
\hline Elongation $(\%)$ & 13 & 22 & 22 & $12-17$ \\
\hline
\end{tabular}


Table 3: Standard Chemical Composition of Materials[6][7]

\begin{tabular}{|l|c|c|c|c|}
\hline \multicolumn{1}{|c|}{ Elements } & En19 & SAE8620 & En24 & AL6061 T6 \\
\hline Aluminium & - & - & - & $95.8-98.6$ \\
\hline Carbon & $0.36-0.44$ & $0.17-0.23$ & $0.35-0.45$ & - \\
\hline Copper & - & - & - & $0.15-0.4$ \\
\hline Chromium & $0.9-1.2$ & $0.9-1.2$ & $0.90-1.40$ & $0.04-0.35$ \\
\hline Nickel & - & - & $1.30-1.80$ & - \\
\hline Iron & $96.7-97.8$ & $96.8-97.9$ & $96.7-94.8$ & $0.7 \max$ \\
\hline Manganese & $0.7-1$ & $0.6-0.95$ & $0.45-0.7$ & $0.15 \max$ \\
\hline Magnesium & - & - & - & $0.8-1.2$ \\
\hline Molybdenum & 0.202 & $0.25-0.35$ & $0.20-0.40$ & - \\
\hline Titanium & - & - & - & $0.15 \max$ \\
\hline Phosphorus & $0.035 \max$ & $0.04 \max$ & $0.04 \max$ & - \\
\hline Zinc & - & - & - & $0.25 \max$ \\
\hline Sulphur & $0.04 \max$ & $0.04 \max$ & $0.04 \max$ & - \\
\hline Silicon & $0.1-0.4$ & $0.1-0.4$ & $0.10-0.35$ & $0.4-0.8$ \\
\hline Other, each & - & - & - & 0.05 \\
\hline
\end{tabular}

\section{Testing Methodology}

Hardness Testing -Rockwell hardness test is performed to determine the hardness of the materials. According to ASTM E-18 standards, hardness of materials is tested on A, B and C scale with a load of 60, 100 and 150kgf respectively, in a dwell time duration of 5 seconds. For En19, En24, SAE8620 materials is tested on A and C scale with a diamond indenter and for AL6061, T6 is tested on A and B scale with a1/16"ball indenter. The result of hardness is average of 6 trials of each specimen.

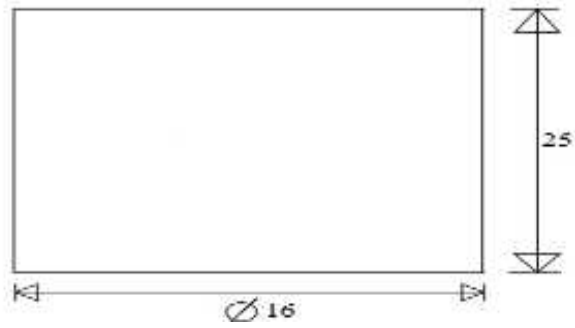

Figure 1: Hardness Testing Specimens Dimension

Impact Testing - Izod and Charpy test is conducted as per ASTM E-23 standards to determine the toughness or impact strength of the materials. It involves the specimen to be struck by the impact strength of $30 \mathrm{~kg}$ (300J) with a speed of $5 \mathrm{~m} / \mathrm{s}$ for Charpy test and for Izod test, the impact strength is $16.4 \mathrm{kgm}(164 \mathrm{~J})$. The pendulum hammer is raised as per the standards for the Izod and Charpy test depending upon the type on specimen to be tested. The pendulum converts its potential energy into kinetic energy, just before it strikes the specimen. This test shows whether the material is ductile or brittle in nature. 

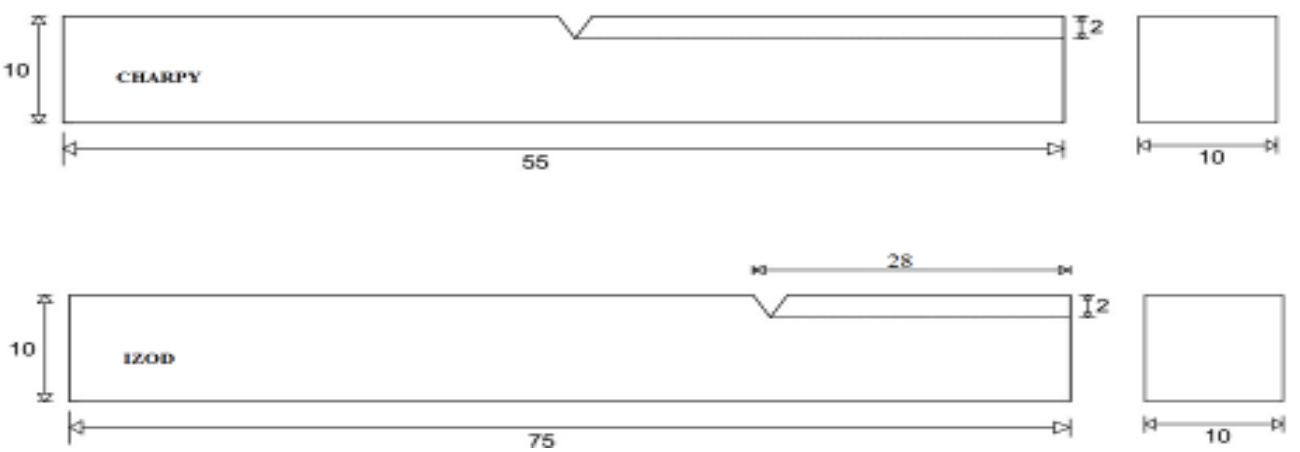

Figure 2: Impact Testing Specimens Dimension

Double Shear Testing - The most common use of a shear testing is to determine the maximum shear strength of the materials. Universal testing machine is used for performing shear, compression and tension. The force applied in shear test is parallel to the two contact surface whereas, in tension and compression, they are perpendicular to the contact surfaces.
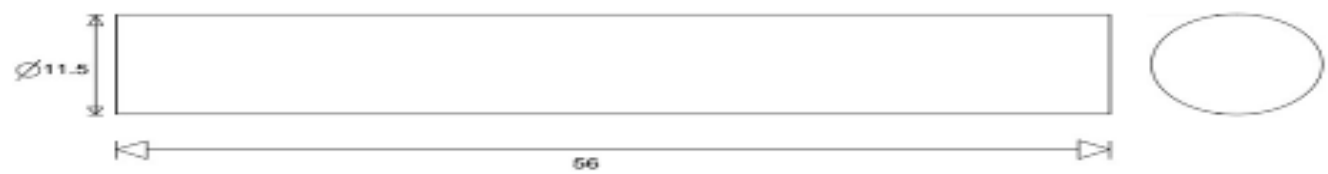

Figure 3: Double Shear Testing Specimen Sizes and Materials

Fatigue testing - Fatigue test is the method for determining the behaviour of materials under fluctuating loads. A cyclic load is applied to the specimen until it breaks in order to measure the fatigue resistance of the material. The fatigue life is indicated by the number of cycles to failure, $\mathrm{N}$. The fatigue testing is conducted by using a rotating beam fatigue tester. The machine can record the number of cycles to failure with the counter.
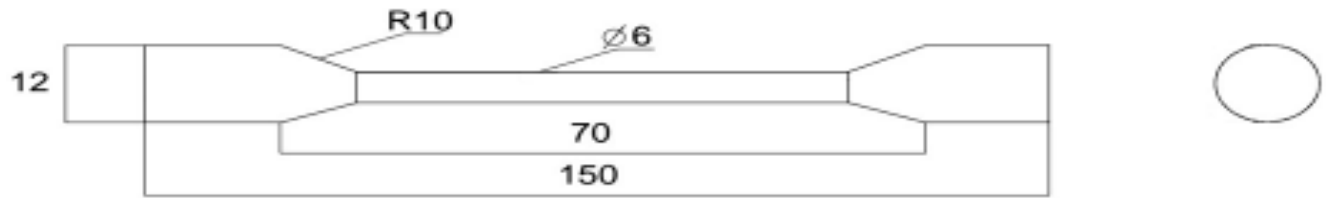

Figure 4: Fatigue Testing Specimens Dimension

Tensile testing - Tensile testing is most common methods for determining materials properties. It is also known as tension testing, is a fundamental materials science test, in which, a specimen is subjected to a controlled tension until failure. The tensile test has been carried out on computerized Universal Testing Machine (UTM) of 1000 KN capacity.
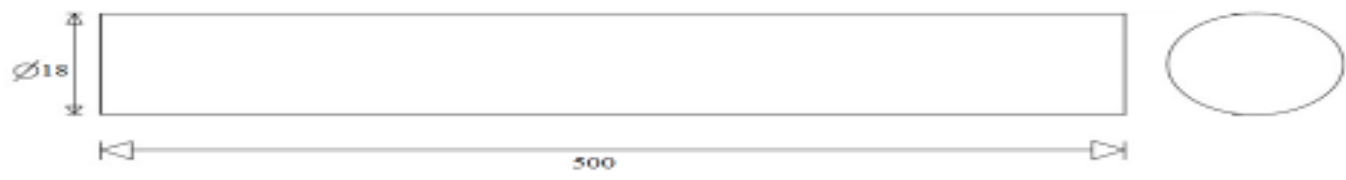

Figure 5: Tensile Testing Specimens Dimension

Energy Dispersive X-ray spectrometry - EDX uses a focused beam of high energy electrons to generate a variety of signals at the surface of solid materials, which is present in Scanning Electron Microscope (SEM).It is an analytical technique used for chemical composition and elemental analysis 


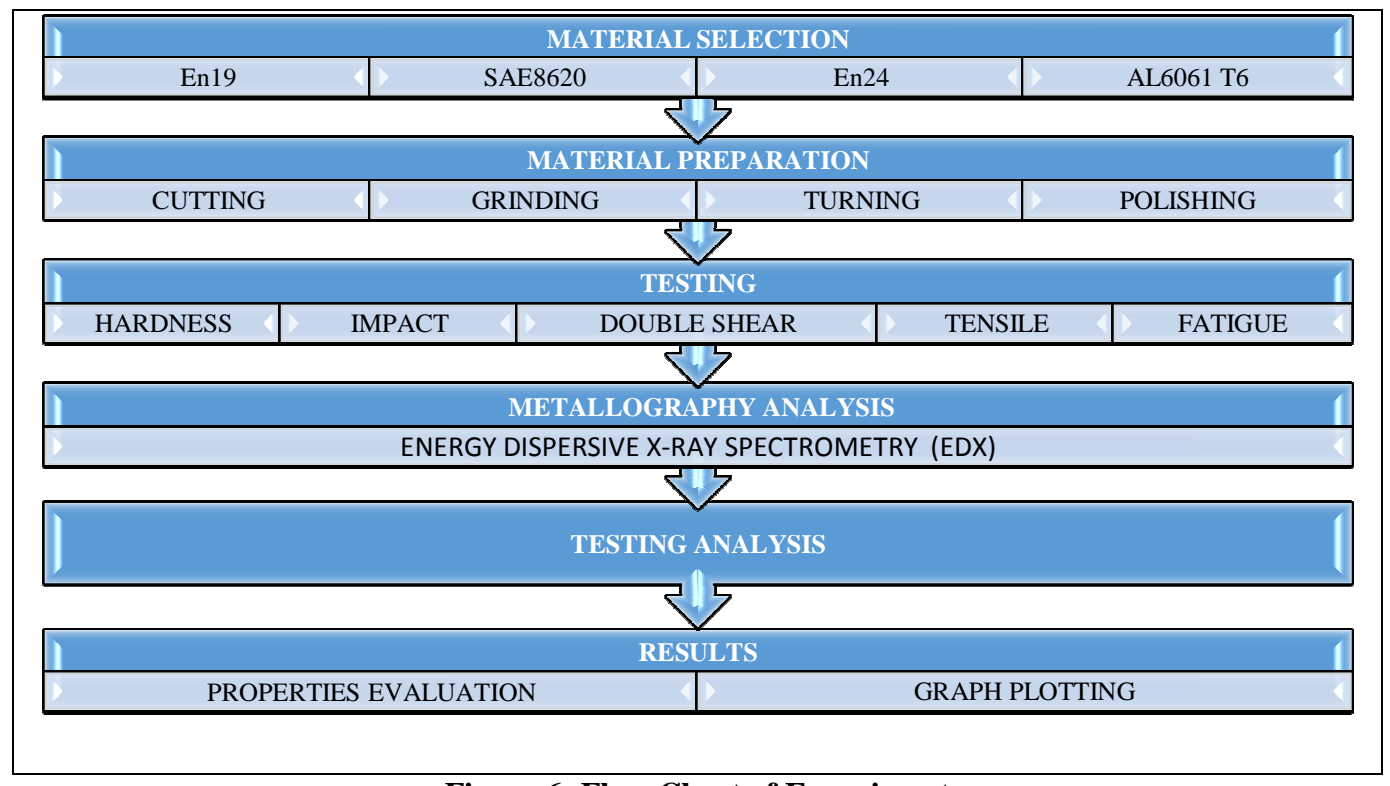

Figure 6: Flow Chart of Experiment

\section{RESULTS}

\section{Mechanical Testing}

Hardness test - The resistance to indentation value of specimens and materials is shown in Figure 7. Rockwell hardness machine test results is tabulated in Table 4and compared by Table 5. This show, which specimens is harder than other materials which are selected by Table 1, after studies of components. Figure 8 shows the specimens after hardness test.

Table 4: Rockwell Hardness Test Results

\begin{tabular}{|l|c|c|c|}
\hline \multirow{2}{*}{ Specimens } & \multicolumn{3}{|c|}{ Unit } \\
\cline { 2 - 4 } & HRA & HRC & HRBw \\
\hline En19 & 64.45 & 28.75 & - \\
\hline En24 & 61.23 & 21.40 & - \\
\hline SAE8620 & 57.66 & 17.86 & - \\
\hline AL6061 T6 & 27.7 & - & 14.18 \\
\hline
\end{tabular}

Table 5: Comparing Hardness Materials Properties[8]

\begin{tabular}{|l|c|c|c|}
\hline \multirow{2}{*}{ Materials } & \multicolumn{3}{|c|}{ Unit } \\
\cline { 2 - 4 } & HRA & HRC & HRBw \\
\hline SAE1548 & 59 & 17 & - \\
\hline En353 & 72 & 43 & - \\
\hline SAE1541 & 50 & 12 & - \\
\hline En47 & 58 & 14 & - \\
\hline AA5454 & 24 & - & 12 \\
\hline AA5182 & 21 & - & 11 \\
\hline
\end{tabular}




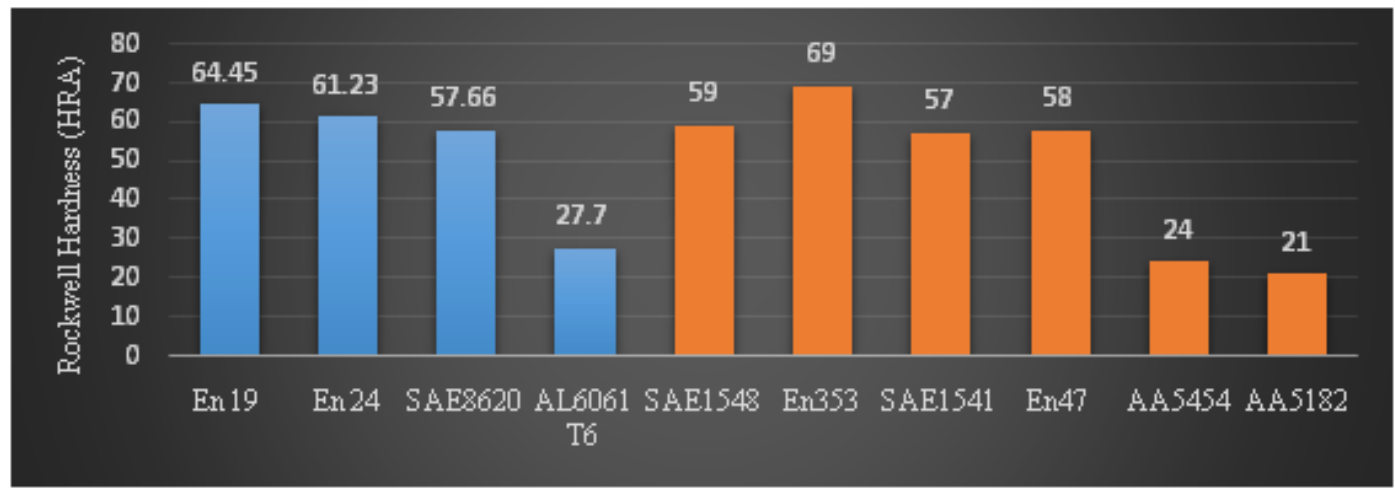

Figure 7: Rockwell Hardness Test

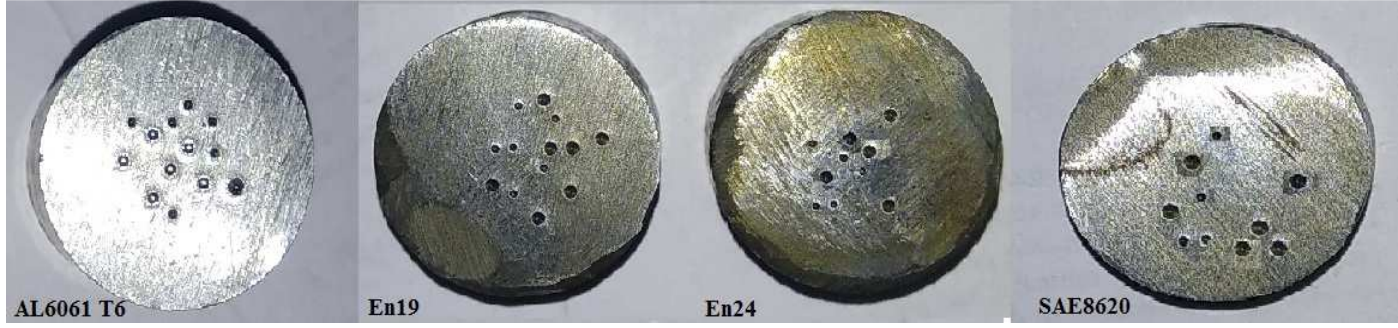

Figure 8: Hardness Test Specimens

Impact test -The resistance of material to resist an impact or sudden load applied is impact strength. The results measured in terms of energy (joules) are shown in Table 6 and the comparing material which is taken from Table 1; those values are shown in Table 7. The graph in Figure 9 shows the Izod and Charpy values of both Table 4 and Table 5. Figure 10 and Figure 11 shows the specimens after performing test.

Table 6: Impact Test Results

\begin{tabular}{|l|c|c|}
\hline \multicolumn{1}{|c|}{ Specimens } & $\begin{array}{c}\text { Izod Testing } \\
\text { (Joules) }\end{array}$ & $\begin{array}{c}\text { Charpy Testing } \\
\text { (Joules) }\end{array}$ \\
\hline En24 & 162 & 210 \\
\hline En19 & 46 & 90 \\
\hline SAE8620 & 60 & 140 \\
\hline AL6061 T6 & 30 & 100 \\
\hline
\end{tabular}

Table 7: Impact Test Value of Comparing Materials [5]

\begin{tabular}{|l|c|c|}
\hline \multicolumn{1}{|c|}{ Materials } & $\begin{array}{c}\text { Izod Value } \\
\text { (Joules) }\end{array}$ & $\begin{array}{c}\text { Charpy Value } \\
\text { (Joules) }\end{array}$ \\
\hline SAE1548 & 85 & 41 \\
\hline En353 & 115 & 50 \\
\hline SAE1541 & 80 & 39 \\
\hline En47 & 27 & 18 \\
\hline AA5454 & 29 & 70 \\
\hline AA5182 & 23 & 65 \\
\hline
\end{tabular}




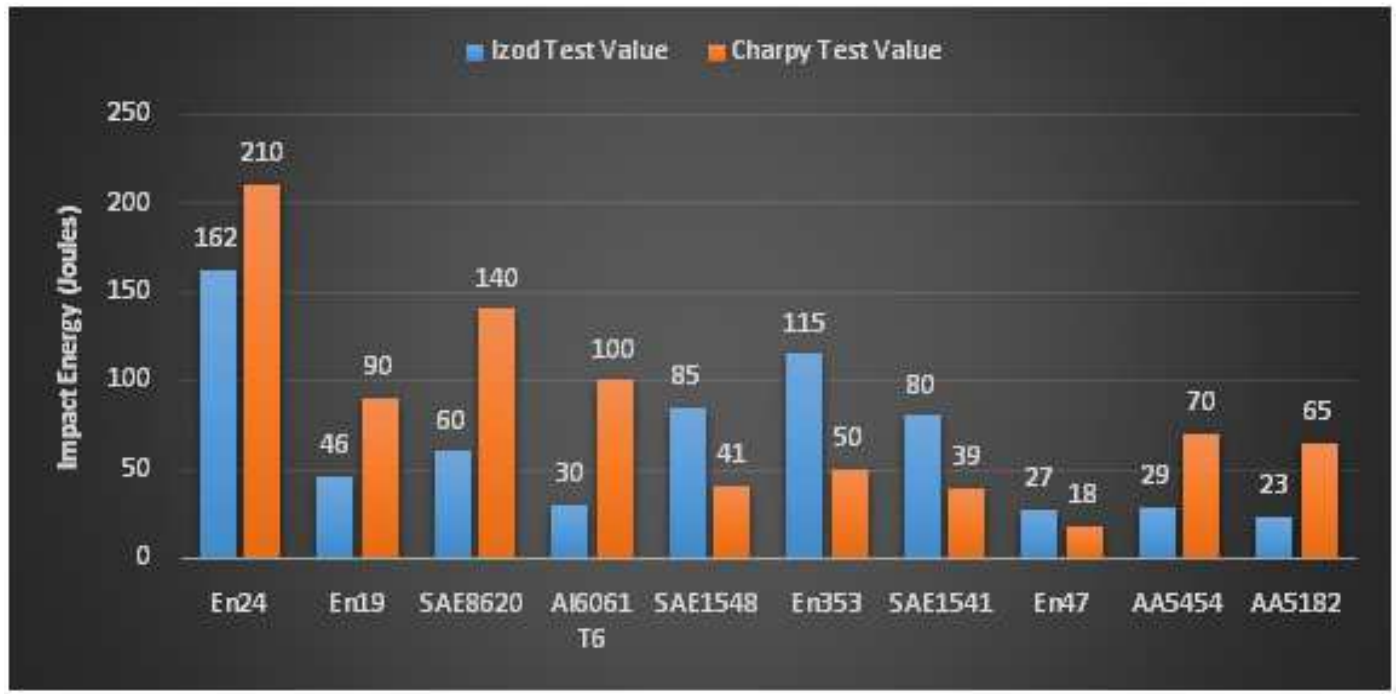

Figure 9: Impact Test Value

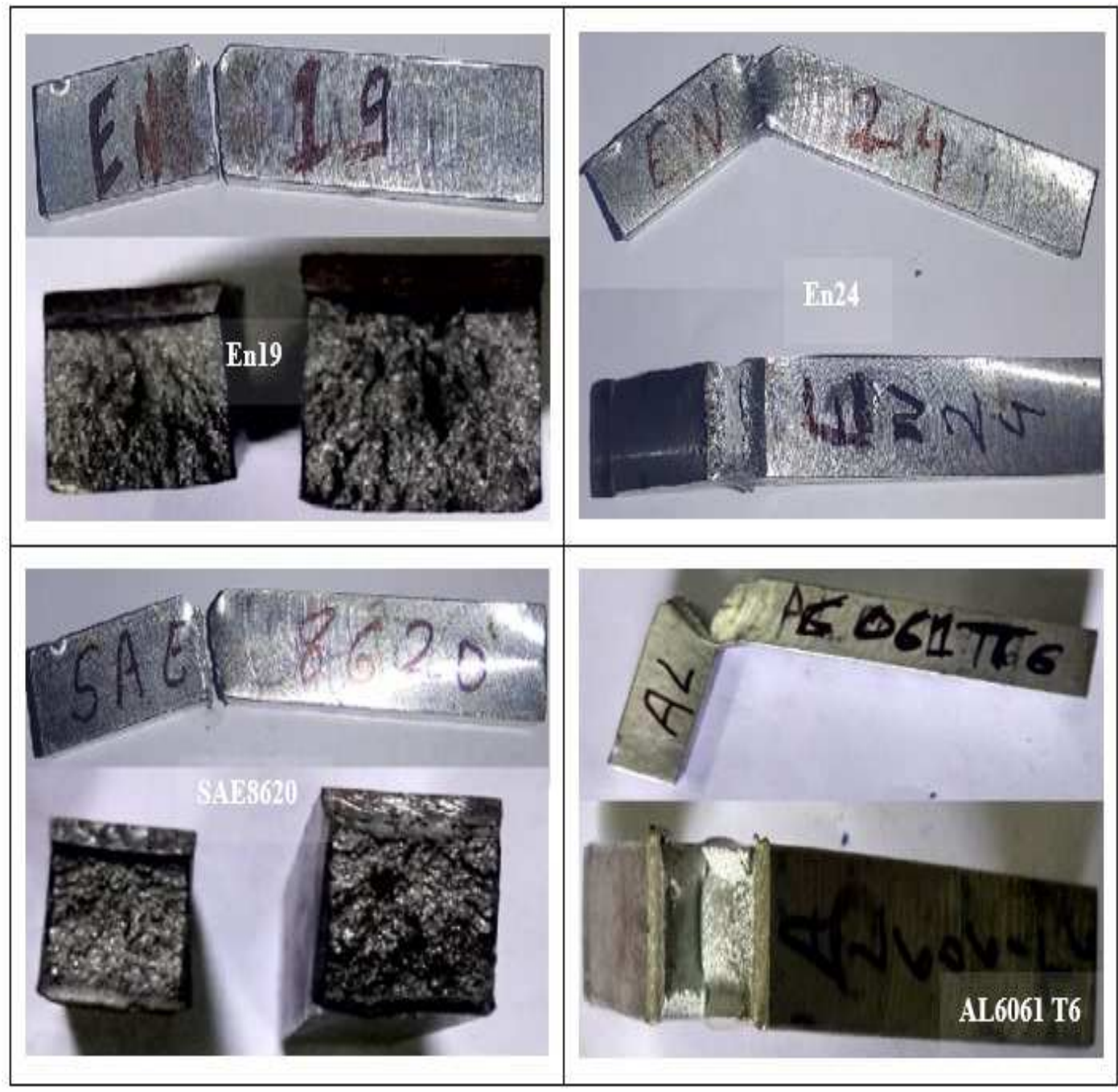

Figure 10: Izod Test Specimens 


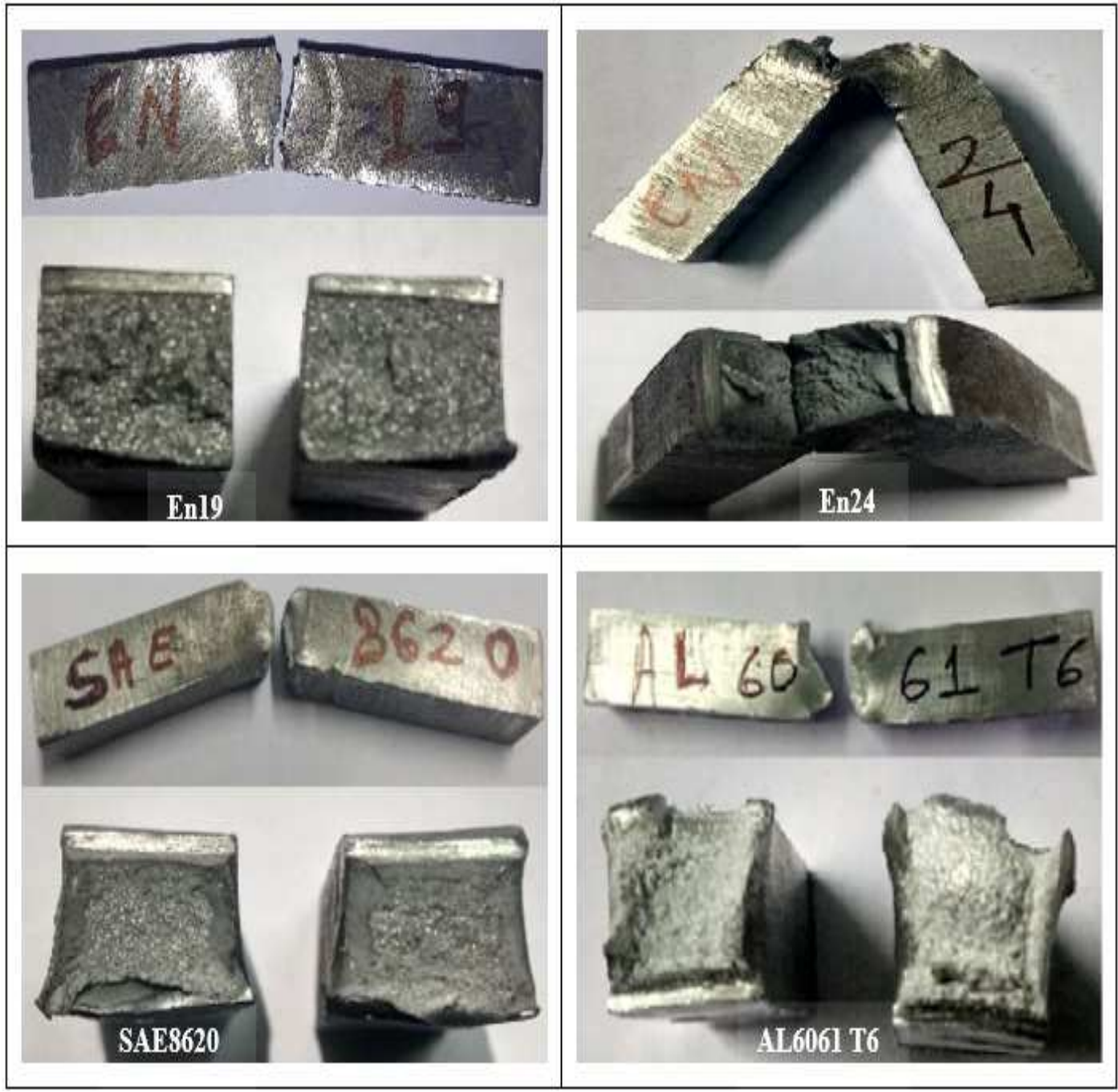

Figure 11: Charpy Test Specimens

Tensile test -Table 8 shows the results of tensile test of specimens done on UTM machine, and Table 9 shows comparing material properties taken from Table 1. Figure 13is generated by computerized UTM machine showings the relationship between Load $(\mathrm{kN})$ and Displacement $(\mathrm{mm})$. Figure 12 shows the specimens after test.

Table 8: Tensile Test Results

\begin{tabular}{|l|c|c|c|c|}
\hline \multicolumn{1}{|c|}{ Properties } & SAE8620 & En19 & En24 & Al6061 T6 \\
\hline Ultimate Tensile Load (kN) & 178.900 & 220.600 & 134.900 & 80.300 \\
\hline Ultimate Tensile Strength (MPa) & 878 & 1110 & 697 & 950 \\
\hline Displacement at Ult. Load (mm) & 29.100 & 46.300 & 46.400 & 30.200 \\
\hline Maximum Displacement (mm) & 37.600 & 54.600 & 57.300 & 42.400 \\
\hline Percentage Elongation (\%) & 17.778 & 68.550 & 27.210 & 21.294 \\
\hline Breaking Load (kN) & 143.000 & 191.600 & 108.200 & 62.700 \\
\hline Breaking Stress (kN/mm $\left.{ }^{2}\right)$ & 0.702 & 0.964 & 0.559 & 0.742 \\
\hline Yield Load (kN) & 157.100 & 178.200 & 75.900 & 47.200 \\
\hline Yield Strength (MPa) & 771 & 897 & 392 & 558 \\
\hline $\begin{array}{l}\text { Displacement at Yield Load } \\
(\mathrm{mm})\end{array}$ & 11 & 24 & 2 & 1 \\
\hline
\end{tabular}


Table 9: Comparing Materials Properties[5]

\begin{tabular}{|l|c|c|c|c|c|c|}
\hline \multicolumn{1}{|c|}{ Properties } & SAE1548 & En353 & SAE1541 & En47 & AA5454 & AA5182 \\
\hline Ultimate Tensile Load (kN) & 167.440 & 165.404 & 169.221 & 170.494 & 66.161 & 106.876 \\
\hline $\begin{array}{l}\text { Ultimate Tensile Strength } \\
\left(\mathrm{kN} / \mathrm{mm}^{2}\right)\end{array}$ & 658 & 650 & 665 & 670 & 260 & 420 \\
\hline Percentage Elongation (\%) & 10 & 12 & 8 & 23 & 14 & 4 \\
\hline Yield Load (kN) & 137.413 & 68.706 & 92.881 & 105.604 & 45.804 & 100.515 \\
\hline Yield Strength (MPa) & 540 & 270 & 365 & 415 & 180 & 395 \\
\hline
\end{tabular}
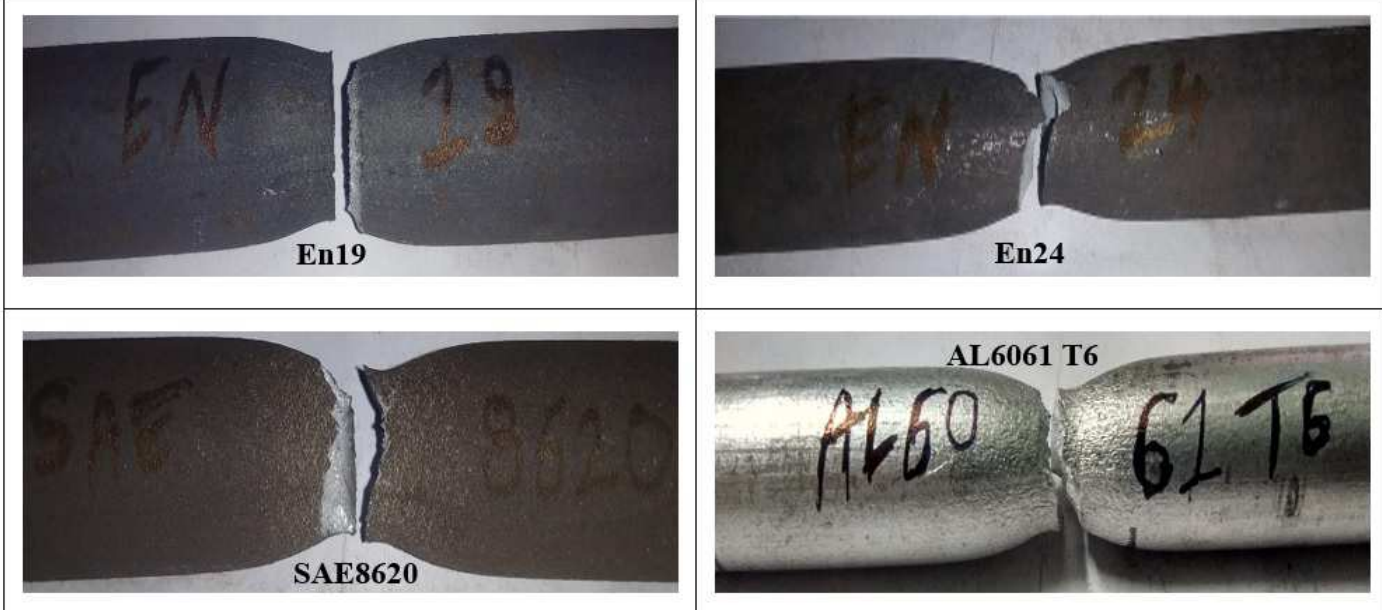

Figure 12: Tensile Test Specimens

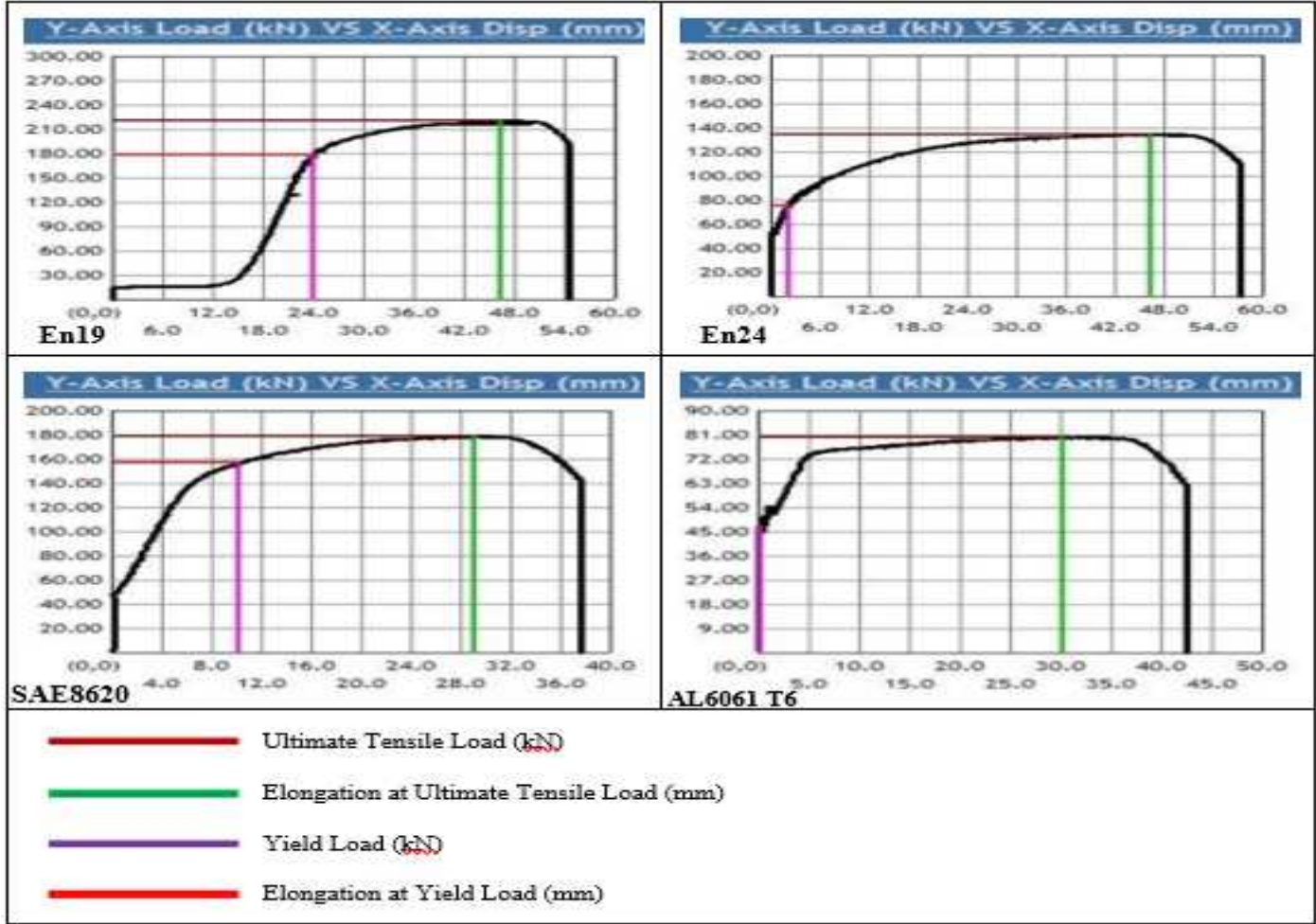

Figure 13: Tensile Test Results 
Fatigue test -A method for determining the behaviour of materials under fluctuating loads. The process of fatigue consists of 3 stages shown in Figure 15 i.e. Initial fatigue damage leading to crack nucleation and crack initiation. Then, Progressive cyclic growth of a crack (crack propagation) until the remaining un-cracked cross section of a part becomes too weak to withstand the loads applied. Finally, sudden fracture of the remaining cross section [9]. Figure 14 shows the relation between stress amplitude and number of cycles. Table 10 shows the results of test. Figure 16 shows specimens after fracture due to loads.

Table 10: Fatigue Test Results

\begin{tabular}{|l|c|c|c|c|}
\hline \multicolumn{1}{|c|}{ Properties } & En24 & EN19 & SAE8620 & AL6061 T6 \\
\hline Total Weight (N) & \multicolumn{4}{|c|}{40.221} \\
\hline Number of Cycles (rpm) & 6245 & 6899 & 9061 & 4010 \\
\hline
\end{tabular}

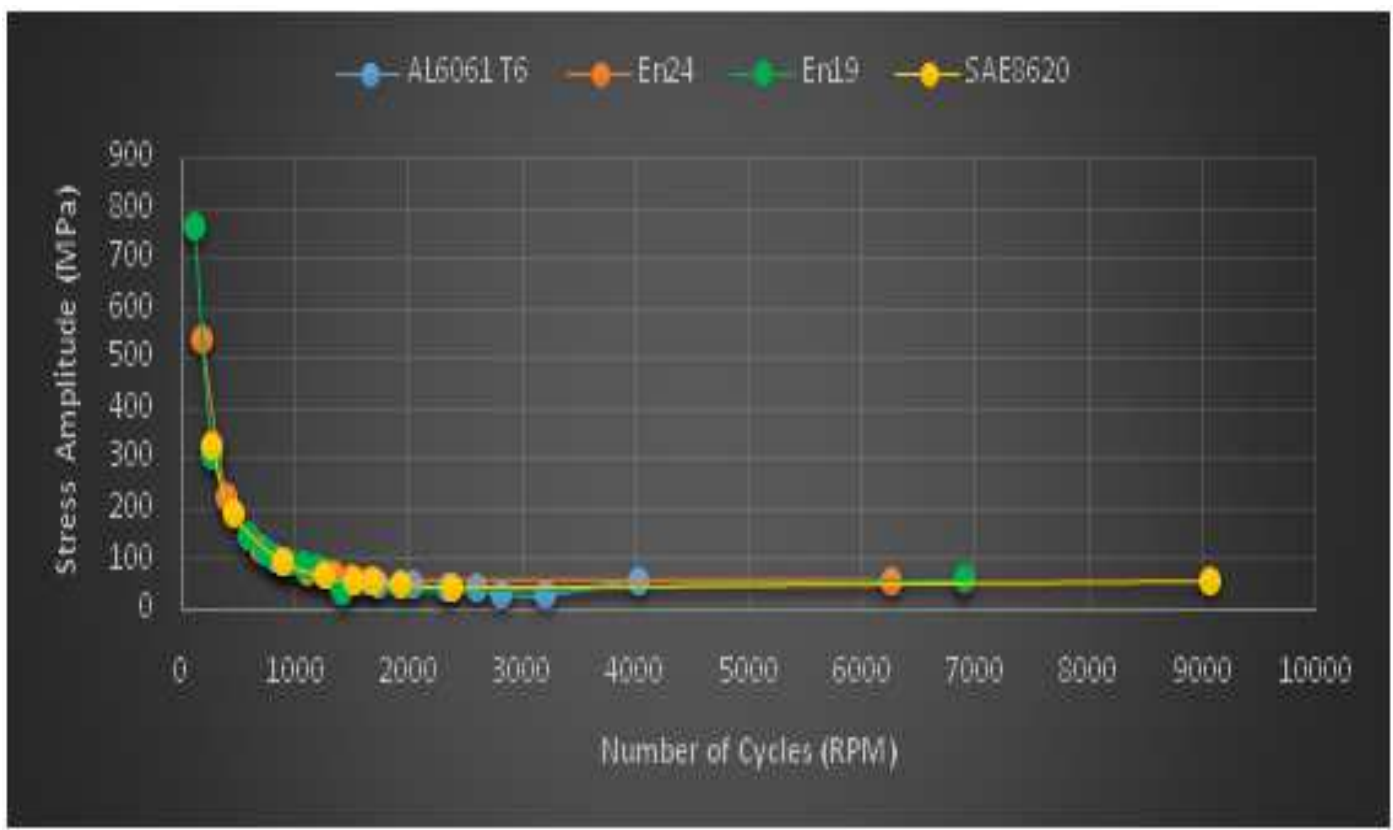

Figure 14: Fatigue Test Results

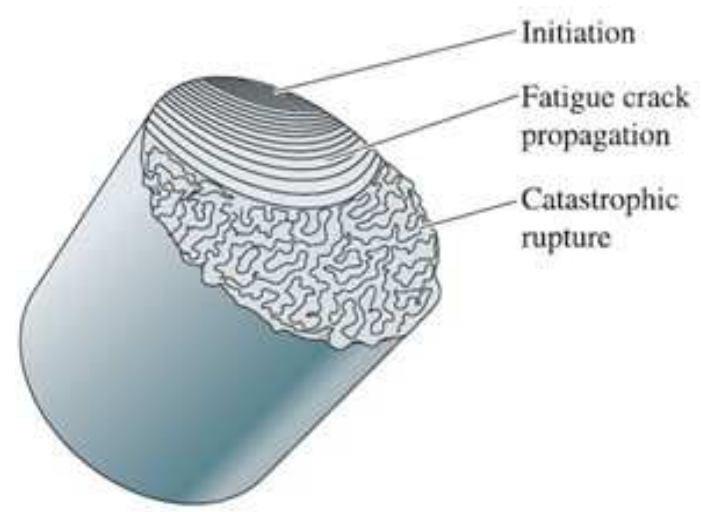

Figure 15: Schematic Representation of a Fatigue Fracture Surface 


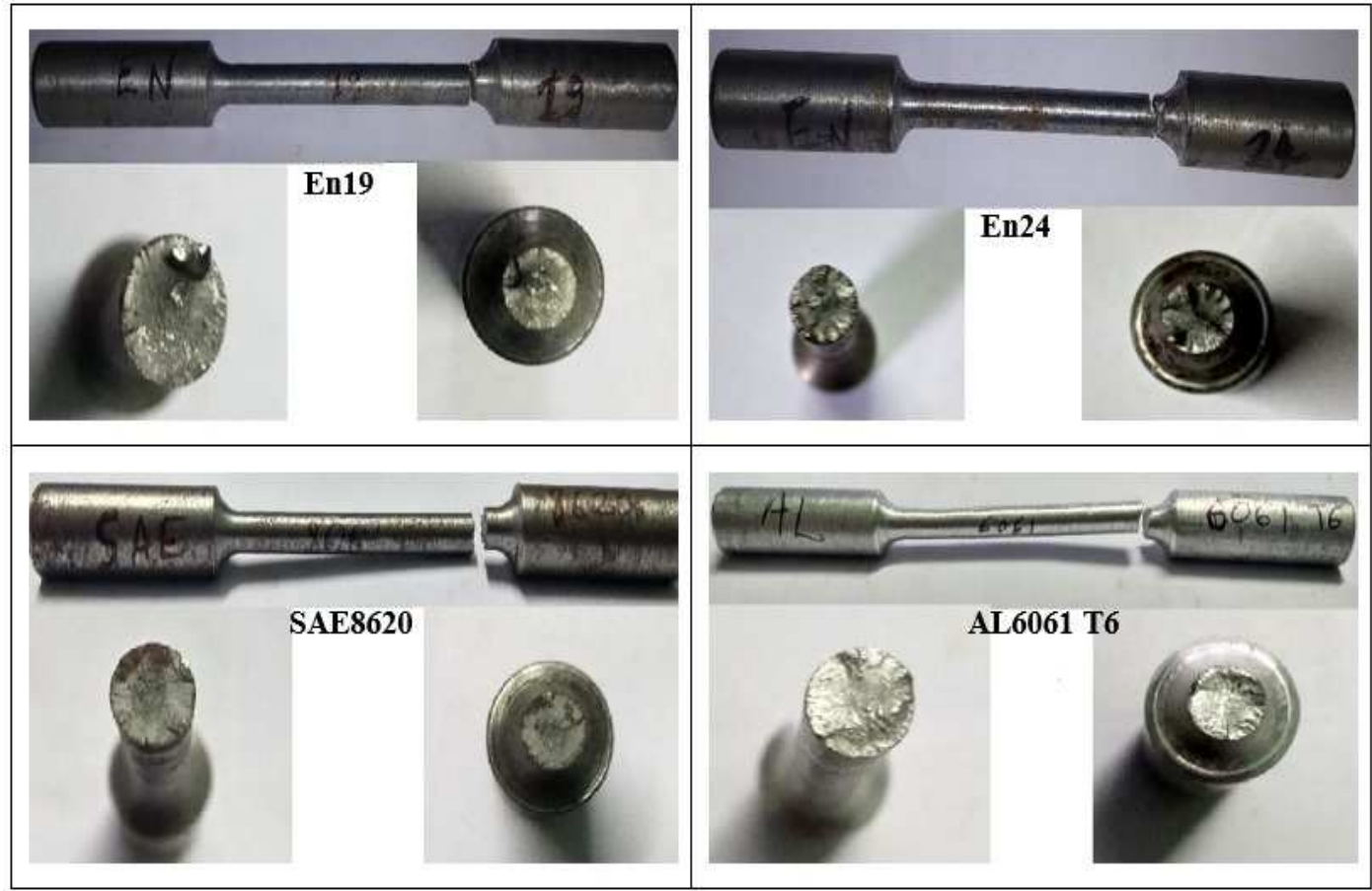

Figure 16: Fatigue Test Specimens

Double shear test - Figure 17 shows the relation between load $(\mathrm{kN})$ and displacement $(\mathrm{mm})$ of specimens. Table 8 and Table 9 shows the maximum shear strength of materials. Figure 18 shows the specimens after fails to withstand shear force.

Table 11:Double Shear Test Results

\begin{tabular}{|c|c|}
\hline Specimens & $\begin{array}{c}\text { Maximum shear } \\
\text { strength }\left(\mathbf{N} / \mathbf{m m}^{\mathbf{2}}\right)\end{array}$ \\
\hline SAE8620 & 404.3559 \\
\hline En19 & 616.1613 \\
\hline En24 & 428.4247 \\
\hline AL6061 T6 & 173.9537 \\
\hline
\end{tabular}

Table 12: Comparing Materials Properties [5]

\begin{tabular}{|l|c|}
\hline \multicolumn{1}{|c|}{ Materials } & $\begin{array}{c}\text { Maximum shear } \\
\text { strength } \mathbf{( N / \mathbf { m m } ^ { 2 }} \text { ) }\end{array}$ \\
\hline SAE1548 & 357 \\
\hline En353 & 421 \\
\hline SAE1541 & 343 \\
\hline En47 & 540 \\
\hline AA5454 & 160 \\
\hline AA5182 & 150 \\
\hline
\end{tabular}




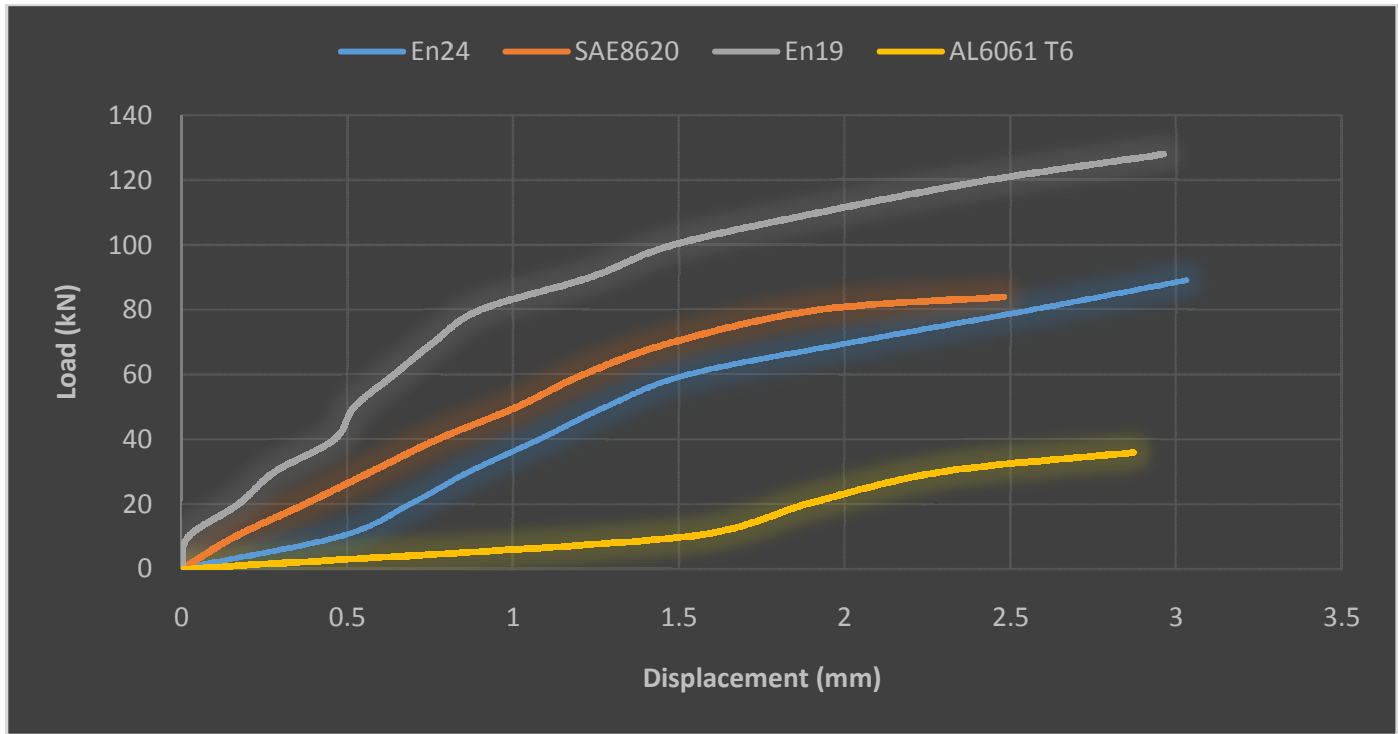

Figure 17:Double Shear Test Results

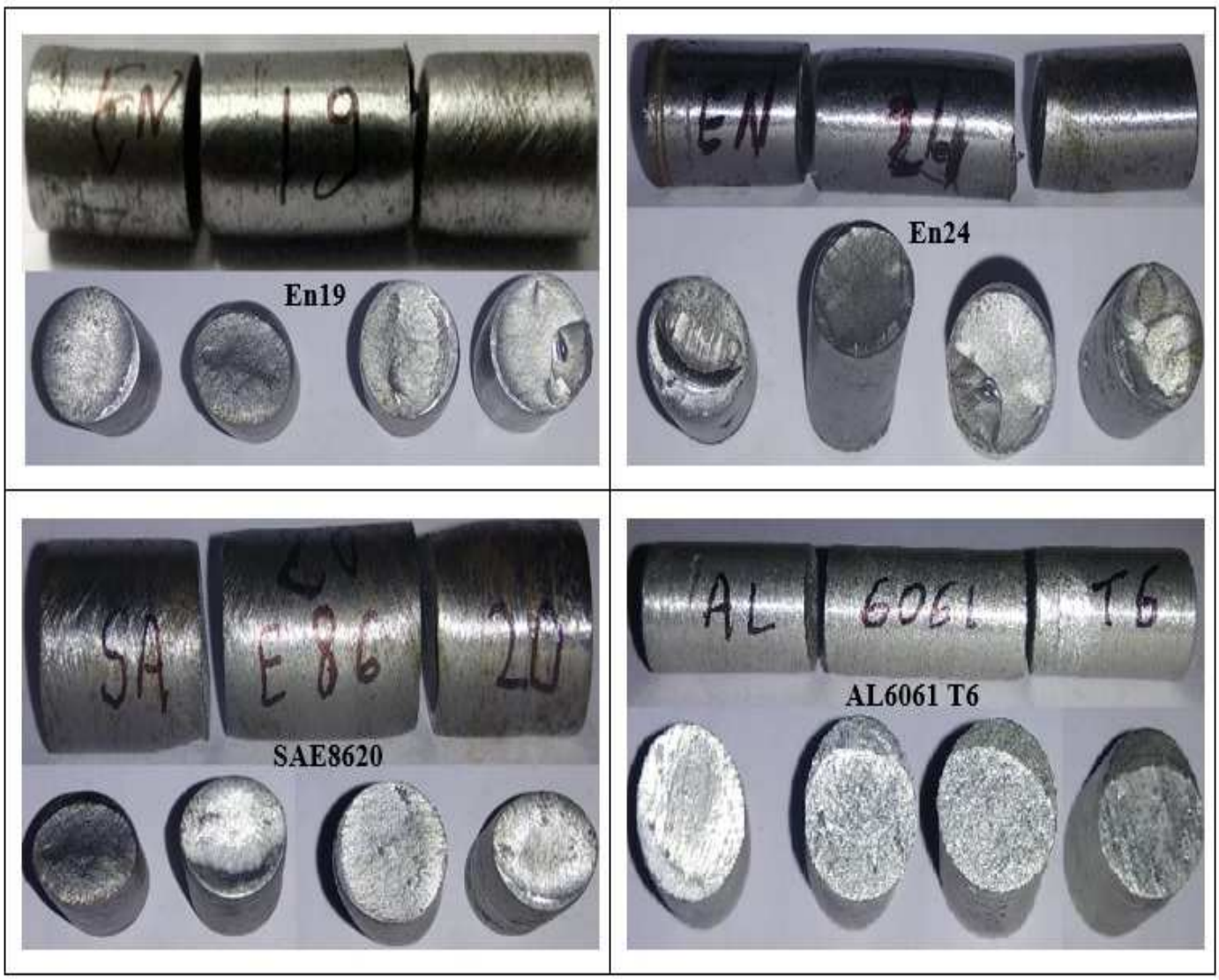

Figure 18: Double Shear Test Specimens

\section{Microstructure Analysis}

EDX - The chemical composition of the specimens traced in EDX analysis are tabulated in Table 13 and the peak of elements can be seen in Figure 19. 
Table 13: Chemical Composition of Materials Traced in EDX Analysis

\begin{tabular}{|l|c|c|c|c|}
\hline \multicolumn{1}{|c|}{ Element } & En19 & SAE8620 & En24 & Al6061 T6 \\
\hline Manganese & 0.72 & - & - & - \\
\hline Phosphorus & 0.01 & 0.10 & 0.09 & - \\
\hline Sulphur & 0.17 & 0.11 & 0.12 & - \\
\hline Silicon & 0.42 & - & 0.39 & 0.45 \\
\hline Nickel & - & 1.44 & 0.50 & - \\
\hline Chronium & 1.35 & 1.24 & 0.58 & - \\
\hline Iron & 97.33 & 96.21 & 97.49 & - \\
\hline Copper & - & - & - & - \\
\hline Magnesium & - & - & - & 0.40 \\
\hline Titanium & - & - & - & - \\
\hline Zinc & - & - & - & - \\
\hline Aluminium & - & - & - & 99.15 \\
\hline
\end{tabular}
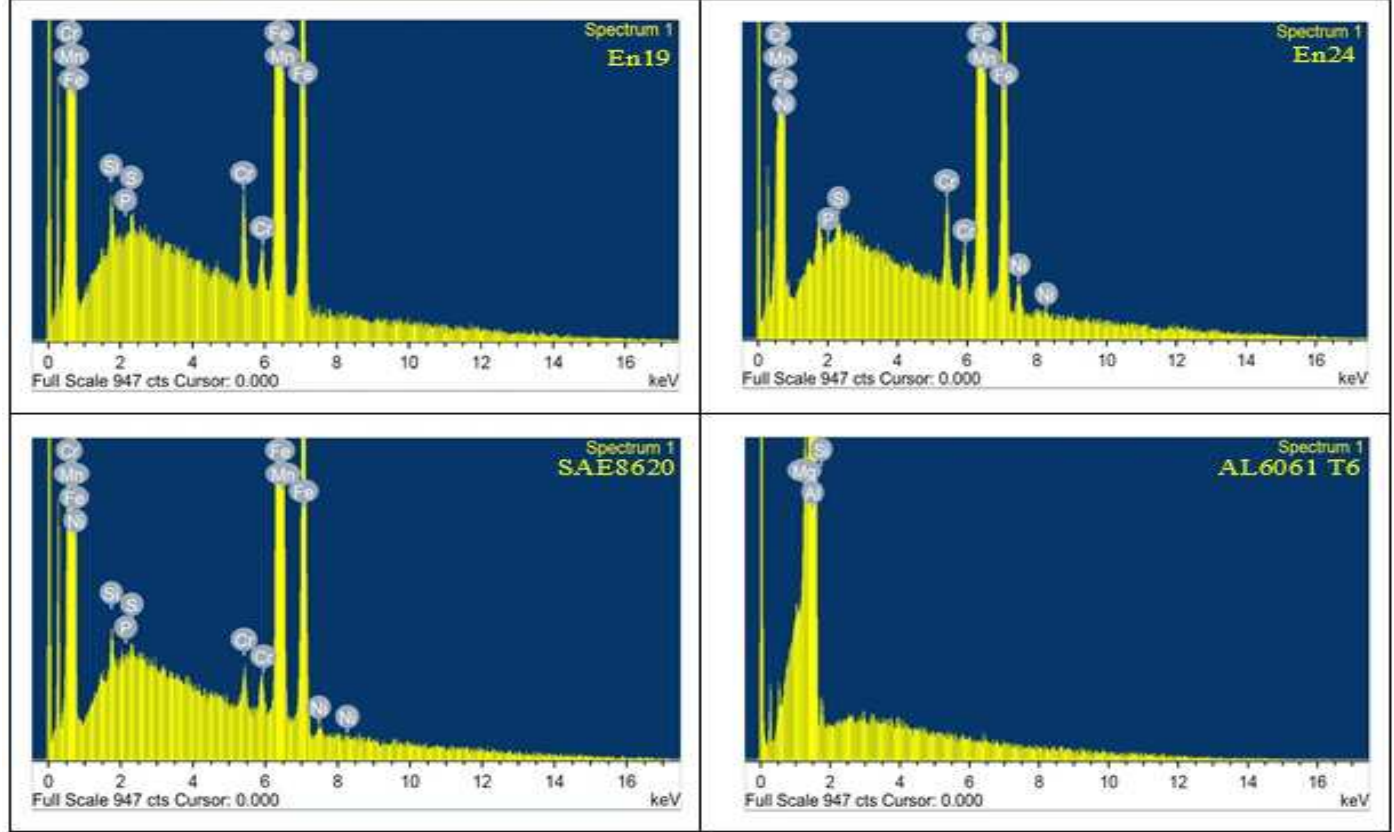

Figure 19:Elemental Composition of Specimens

\section{CONCLUSIONS}

In these experiments, the tests were conducted to find the alternatives materials that are not used currently in that components manufacturing. After evaluating the results, En19 is found to be the best alternative for manufacturing of cylinder in engine components as well as AL6061. T6 can also be used because; it has high ultimate strength and yield strength, at the same time, low density. For Piston, SAE8620 has high fatigue life and more toughness as shown in graph due to presence of nickel. Connecting rod and Crankshaft have high strength. So, En24 is good for manufacturing. En19 also has good wearing properties as revealed in the paper, and it is easy to shape, so, it is good for gears manufacturing. For Propeller shaft, SAE8620 is the best because, it can take a lot of fatigue. An Axle Beams should have high strength and low density. So, En24 is better than, as well as SAE8620 can be used.En19 is better for Steering Knuckle because, it has high tensile strength and toughness. Chassis has to bear a lot of loads, and doors of the vehicle has to resist more impact, at the same time, both have to be light-weight, so, AL6061 T6 is the best replacement for the manufacturing. 


\section{REFERENCES}

1. India Brand Equity Foundation, “Automobile Industry in India”, 2017. Retrieved from https://www.ibef.org/industry/indiaautomobiles.aspx

2. J.B. Maverick, "What types of raw materials would be used by an auto manufacturer?”, 2013.

3. Mr. Bennett, "The Automobile Industry Goes on a Diet”, The Wall Street Journal, 2016.

4. Kalyani Steels, "Rolled Bars for Automotive Application”. Retrieved from http://www.kalyanisteels.com/product/

5. Material Property Data, Retrieved from http://www.matweb.com/search/DataSheet.aspx?MatGUID= $\underline{b 8 d 536 e 0 b 9 b 54 b d 7 b 69 e 4124 d 8 f 1 d 20 a}$

6. SAE Steel Grades, Retrieved from http://www.qtstools.com/TechInfo/SAE\%20steel\%20grades.htm

7. Material Science, Retrieved from http://www.azom.com/article.aspx?ArticleID=6742

8. American National Standard, "Standard Test Methods for Rockwell Hardness of Metallic Materials", ASTM International.

9. Materials Testing Non-destructive testing and Calibration Services, Retrieved from https://www.labtesting.com/ services/materials-testing/mechanical-testing/impact-testing/

10. Test Resources, Retrieved from http://www.testresources.net/applications/test-types/shear-test/

11. Instron, Retrieved from http://www.instron.in/en-in/our-company/library/glossary/f/fatigue-test

12. Daudi S. Simbeye, "Computerized Measurement and Control System of the Universal Testing Machine Based On Virtual Instruments”, JISCT, Vol.5, Issue.2, 2016.

13. Kouichi Tsuji, “X-ray Spectrometry”, Analytical Chemistry, Vol.82, Issue.12, 2010.

14. Hardness Convert, Retrieved from www.efunda.com/units/hardness/convert_hardness.cfm

15. H.E. Boyer, "Fatigue Testing”, 1986

16. F. V. Lawrence, "Mechanisms of Fatigue Crack Initiation and Growth”, pp.1-34, 2014.

17. Northwest aluminium specialties, Inc., 2011 Retrieved from http://www.nwaluminum.com/Translations/French/Analysis.html

18. Navin A. Astunkar, A. S. Bonde, "Effect of Hardness and Wear Resistance on En353 Steel by Heat Treatment", IJMER.

19. Tridib Kumar Mahata, “Analysis of Mechanical Properties of En24 steel after Austempering and Martepering”, Vol.5, Issue.3.

20. M. Uma Shankaran, "Metallurgical Test on 20MnCr5 Steel: To Suggest as a Suitable Crankshaft Material"

21. A. Raveendra, "Micro-Hardness and Mechanical Properties of En24 Alloy Steel”, IJI. 